Page 1 of 2

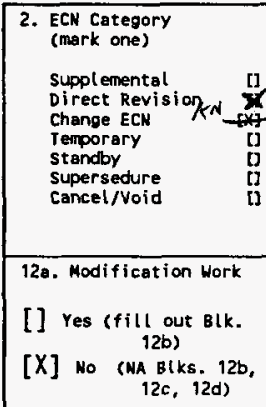

13a. Description of Change
3. Originator's Nane, Organization, MSIN, and Telephone No.

G. W. Ryan, 8M100, A3-37, 376-5114

\begin{tabular}{|l|l}
\hline 6. Project Title/No./Work order No. & 7. Bldg./Sys./Fac. No.
\end{tabular} TWRS FSAR Development

9. Document Numbers Changed by this ECK (includes sheet no. and rev.) WHC-SD-WM-CN-056, REV. 1 \begin{tabular}{l|l} 
12b. Work Package \\
No.
\end{tabular}
5. Date

August 27, 1996

$\begin{aligned} & \text { 4. Uso Required? } \\ & \text { [] Yes [x] Ho } \\ & \text { 7. Bldg./Sys./Fac. No. } \\ & \text { Tank Farms }\end{aligned}$
$\begin{gathered}\text { 10. Related ECN Ho(s). } \\ \text { N/A }\end{gathered}$

8. Approvol Designator

N/A

11. Related PO No.

$N / A$

12d. Restored to Original Condition (Terp. or Standby ECW only) $N / A$

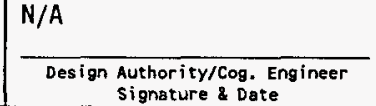

13b. Design Baseline Document?
Design Authority/Cog. Engineer Signature \&ate

Full revision of WHC-SD-WM-CN-056, Rev. 1 to Rev. 2.

NOTE: ACCORDING TO SECTION WP-6.7, REV, O OF WHC-CM-6-32, SAFETY ANALYSTS AND NUCLEAR ENGINEERING WORK PROCEDURES, CALCULATION NOTES ARE USED TO DOCUMENT THE ORIGINATOR'S ANALYSIS BUT ARE NOT TO BE USED TO AUTHORIZE ACTIVITIES OR JUSTIFY FACILITY MODIFICATIONS, OR CHANGES TO AN AUTHORIZATION BASIS, SAFETY BASIS, OR DESIGN BASIS.

14a. Justification (mark one)

Criteria Change $[X]$ Design Improvement

As-Found

[] Facilitate Const

[1] Enviromental

[] Facility Deactivation []

Const. Error/Omission

Design Error/Onission

14b. Justification Details

The revision to this document was necessitated due to the functional review of FSAR text related to this calculation note.

15. Distribution (include nane, MSIN, and no. of copies)

See attached distribution list.

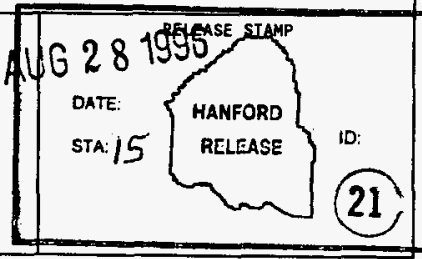

A-7900-013-2 (05/96) GEF095 
ENGINEERING CHANGE NOTICE

1. ECN (use no. from pg. 1)

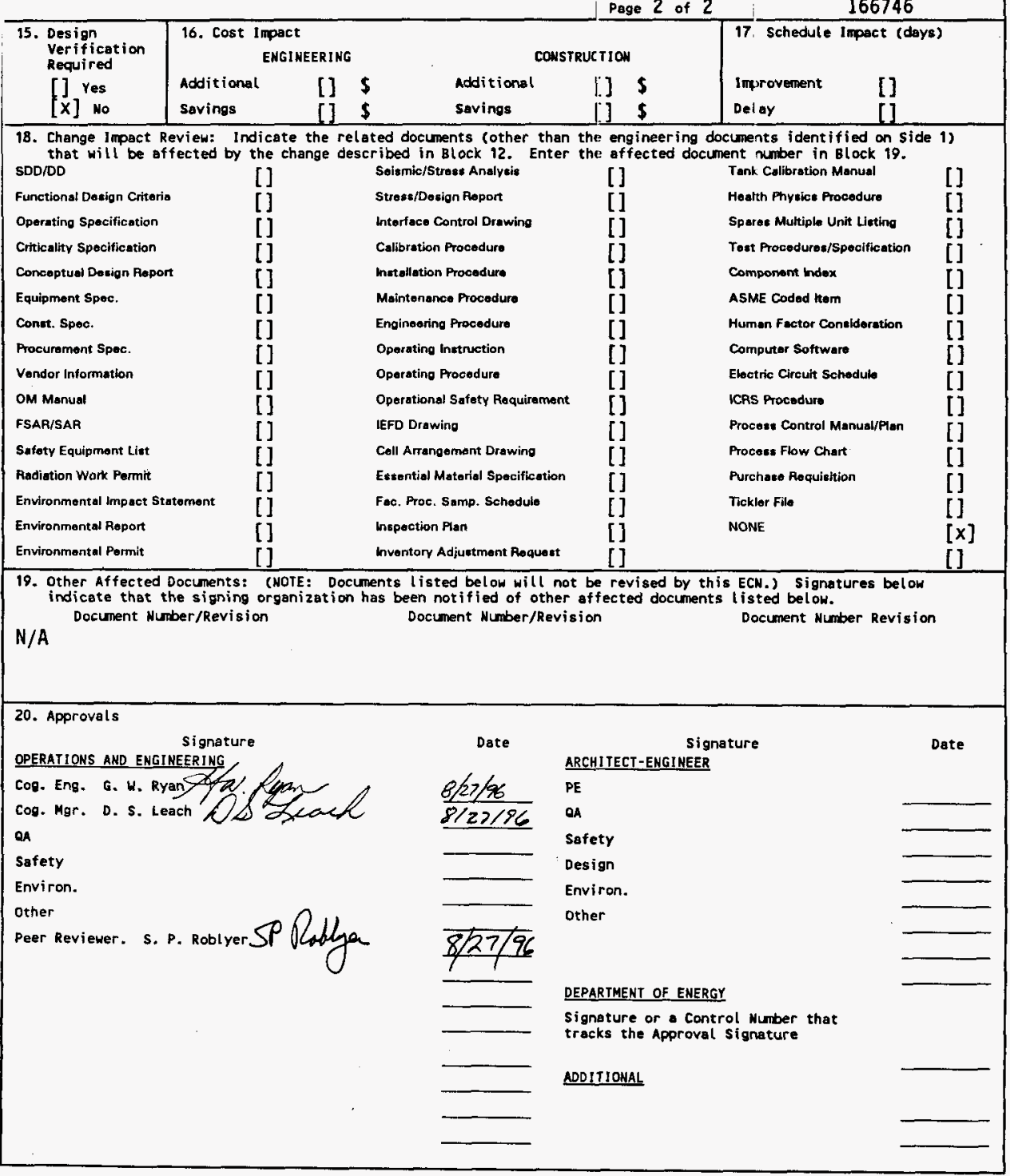




\title{
Fire in a Contaminated Area
}

\author{
G. W. Ryan
}

West inghouse Hanford Company, Richland, WA 99352

U.S. Department of Energy Contract DE-AC06-87RL10930
EDT/ECN: $\quad 166746$
Org Code: 8 M100
UC: 510
B\&R Code: EW3120071
Charge Code: NIFC3
Total Pages: 39

Key Words: contaminated fire, fire, radioactive materials, tank farms, transfers, TWRS, valve pit

Abstract: This document supports the development and presentation of the following accident scenario in the TWRS Final Safety Analysis Report:

\section{Fire in Contaminated Area}

The calculations needed to quantify the risk associated with this accident scenario are included within.

IRADEMARK DISCLAIMER. Reference herein to any specific comercial product, process, or service by trade nane, trademark, manufacturer, or otherwise, does not necessarily constitute or imply its endorsement, recomendation, or favoring by the United States Government or any agency thereof or its contractors or subcontractors.

Printed in the United states of America. To obtain copies of this document, contact: WHC/BCS Document Control 5ervices, P.O. Box 1970, Mailstop H6-08, Richland WA 99352, Phone (509) 372-2420; Fax (509) 376-4989.
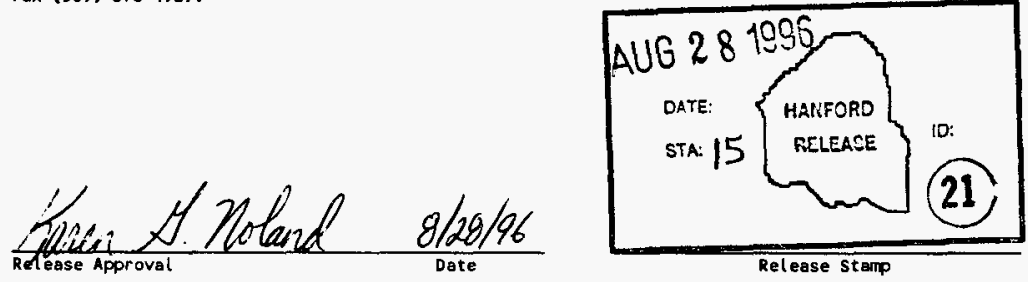

Release Stamp

Approved for Public Release 
(2) Title

Fire in a Contaminated Area

CHANGE CONTROL RECORD

\begin{tabular}{|c|l|} 
(3) Revision & (4) Description of Change - Replace, Add, and Delete Pages \\
\hline 0 & (7) New document released \\
\hline 1 & Full revision by ECN\#166745. \\
\hline 2 & Full revision by ECN\#166746. \\
RS & \\
\hline
\end{tabular}

Authorized for Release

(5) Cog. Engr. (6) Cog. Mgr. Date

G. W. Ryan D. S. Leach

\begin{tabular}{l|l}
$8 / 1 / 96$ & $8 / 1 / 96$ \\
\hline
\end{tabular}

G. W. Ryan D. S. Leach

$8 / 8 / 96$

$8 / 8 / 96$

G. W. Ryan

D. S. Leach

8/27/96

$8 / 27 / 96$ 
FIRE IN A CONTAMINATED AREA

REVISION 0

Tank Waste Remediation System Final Safety Analysis Report Project Safety Analysis \& Nuclear Engineering

NOTE: ACCORDING TO SECTION WP-6.7, REV. O OF WHC-CM-6-32, SAFETY ANALYSIS AND NUCLEAR ENGINEERING WORK PROCEDURES, CALCULATION NOTES ARE USED TO DOCUMENT THE ORIGINATOR'S ANALYSIS BUT ARE NOT TO BE USED TO AUTHORIZE ACTIVITIES OR JUSTIFY FACILITY MODIFICATIONS, OR CHANGES TO AN AUTHORIZATION BASIS, SAFETY BASIS, OR DESIGN BASIS. 
WHC-SD-WM-CN-056 REV 2

This page intentionally left blank. 
CONTENTS

1.0 INTRODUCTION AND PURPOSE ................. 7 of 38

2.0 ANALYSIS INPUT .............................. 8 of 38

3.0 ASSUMPTIONS ............................... 8 of 38

4.0 ANALYTICAL METHODS AND CALCULATIONS . . . . . . . . 9 of 38

5.0 RADIOLOGICAL DOSE CONSEQUENCE ANALYSIS . . . . . . . . 12 of 38

6.0 TOXICOLOGICAL EXPOSURE CONSEQUENCE ANALYSIS . . . . . . 14 of 38

7.0 ANALYSIS RESULTS .......................... 15 of 38

8.0 CONCLUSIONS ................................ 16 of 38

9.0 REFERENCES ................................ 16 of 38

\section{APPENDICES}

A ACCIDENT FREQUENCY DEVELOPMENT ............. 17 of 38

B SKETCHES OF TYPICAL VALVE PITS ............ 21 of 38

c INFORMATION VALIDATION FORM ....................... 25 of 38

D SUM-OF-FRACTION OF RISK GUIDELINE FOR UNIT LITER

RELEASE OF CHEMICALS ................ 29 of 38

E PEER REVIEW AND HEDOP REVIEW CHECKLISTS . . . . . . . . 33 of 38 


\section{LIST OF TABLES}

1. ULD for Aging Waste ............... 8 of 38

2. Atmospheric Dispersion Coefficients ........ 8 of 38

3. Sum- of-Fraction of Risk Guidelines for a Unit Release of Chemicals 14 of 38 4. Radiological Dose and Toxicological Exposure Consequences

for Fire in a Contaminated Area Accident Scenario ........ 15 of 38 


\section{LIST OF TERMS}

$\begin{array}{ll}\text { AED } & \text { aerodynamic equivalent diameter } \\ \text { ARF } & \text { airborne release fraction } \\ \text { AWF } & \text { aging waste facility } \\ \text { CEDE } & \text { committed effective dose equivalent } \\ \text { DR } & \text { damage ratio } \\ \text { DST } & \text { double-shell tank } \\ \text { FSAR } & \text { final safety analysis report } \\ \text { HEDOP } & \text { Hanford Environmental Dose Overview Panel } \\ \text { IVF } & \text { information validation form } \\ \text { LPF } & \text { leak path factor } \\ \text { MAR } & \text { material-at-risk } \\ \text { rem } & \text { radiation effective man } \\ \text { RF } & \text { respirable fraction } \\ \text { SST } & \text { single-shell tank } \\ \text { SV } & \text { sievert } \\ \text { TEDE } & \text { total effective dose equivalent } \\ \text { TWRS } & \text { Tank Waste Remediation System } \\ \text { ULD } & \text { unit liter dose } \\ \text { UNH } & \text { uranyl nitrate hexahydrate } \\ \text { VOl\% } & \text { volume percent } \\ \text { WHC } & \text { Westinghouse Hanford Company }\end{array}$


WHC-SD-WM-CN-056 REV 2

This page intentionally left blank. 


\section{FIRE IN A CONTAMINATED AREA}

\subsection{INTRODUCTION AND PURPOSE}

This document supports the development and presentation of the following accident scenario in the TWRS Final Safety Analysis Report (FSAR):

Fire in Contaminated Area.

\section{ACCIDENT SCENARIO DEVELOPMENT AND DESCRIPTION}

Numerous contaminated areas exist within TWRS facilities that are susceptible to releasing hazardous material in the event of a fire. A significant number of these contaminated areas are associated with the waste transfer system. Some of the contaminated areas in the waste transfer system that are routinely accessed include valve pits, pump pits, and diversion boxes. These structures, while being mainly underground, do extend above ground, presenting a hazard associated with the fuel tanks of vehicles operating within close proximity.

The hazard analysis performed for the tank farms identified numerous causes for a fire in a contaminated area. Some of the causes included human error in positioning a crane load, pump motor electrical failure, or a vehicle being driven over a pit cover that ruptures the fuel tank.

Evaluation of the hazards and associated causes allowed the identification of an unmitigated accident scenario that represents a set of hazardous conditions related to fires in contaminated areas. In the unmitigated accident scenario analyzed, a human error occurs such that a crane is positioned near a pit. The fuel tank of the crane or nearby support vehicle hits the pit curb and spills gasoline into the open pit. An ignition source is present and the gasoline in the pit catches fire. Convection from the fire sweeps the hazardous material out of the pit into the atmosphere where it is transported away from the accident location by wind and other atmospheric dispersion phenomena.

The analysis of this unmitigated accident scenario specifically bounds the release of radioactive or toxic materials from a vehicle carrying small waste samples or contaminated equipment due to a vehicle fire.

\section{ACCIDENT FREQUENCY DEVELOPHENT}

A frequency of anticipated was qualitatively assigned to this unmitigated accident scenario. Investigation showed that the frequency of such an event occurring based on one location and one vehicle would be approximately $9.0 \times 10^{-7} / \mathrm{yr}$ (beyond extremely unlikely) [Appendix A]. The frequency analysis was based on the number of miles per year travelled by a single crane or support vehicle near a single pit, as well as vehicle statistics involving fires compiled by the $U$. S. Department of Transportation (WHC-SD-WM-CN-056). However, the overall frequency of an event within the TWRS complex (multiple vehicles and locations) is estimated to be much higher (i.e., anticipated). 
The consequences associated with this accident scenario are compared to the risk acceptance guidelines for anticipated accidents as provided in WHC-CM-4-46, Rev. 1.

\subsection{ANALYSIS INPUT}

- Unit Liter Doses (ULD) for aging waste are given below in Table 1 (Cowley 1996).

Table 1. ULD for Aging Waste.

\begin{tabular}{|c|c|c|}
\hline Waste Material & Inhalation ULD $(\mathrm{SV} / \mathrm{L})$ & Ingestion ULD $\left(\mathrm{Sv}-\mathrm{m}^{3} / \mathrm{s}-\mathrm{L}\right)$ \\
\hline AWF Solids & $1.7 \times 10^{6}$ & 8.1 \\
\hline AWF Liquids & $1.4 \times 10^{3}$ & 0.092 \\
\hline
\end{tabular}

Integrated Atmospheric Coefficients for both onsite and offsite receptors from Van Keuren (1996a) are given in Table 2. The integrated $X / Q^{\prime}$ values are used for releases less than 2 hours in duration.

Table 2. Atmospheric Dispersion Coefficients.

\begin{tabular}{|c|c|}
\hline Receptor & Integrated $\times / Q^{\prime}\left(\mathrm{s} / \mathrm{m}^{3}\right)$ \\
\hline Onsite & $3.41 \times 10^{-2}$ \\
\hline Offsite & $2.83 \times 10^{-5}$ \\
\hline
\end{tabular}

- Dimensions of typical valve pit - The typical valve pit is 12 feet in length and 10 feet wide (inside dimension). A drain is located in one corner approximately 1 foot from the walls. The floor of the pit is sloped from the 4 walls to the drain. The elevation of the floor walls of the pit is 1.5 inches higher than at the drain (see Appendix B for a sketch of a typical valve pit). Additionally, see the approved information validation form (IVF) for this accident scenario in Appendix $C$.

\subsection{ASSUMPTIONS}

- It is assumed that the material at risk is bounded by a one inch deep layer of dried out aging waste material on the floor of a valve pit around the drain. This is based on the observation that the lip of the drain may protrude as much as one inch above the floor in some pits. A typical valve pit was chosen because it is larger than the other types of pits that may contain contaminated material.

- Waste composition is assumed to be 67 vol\% Aging Waste Facility (AWF) liquids and 33 vol\% AWF solids. This is bounding for all possible Hanford waste transfers (Cowley 1996). 
- It is assumed that all of the hazardous material is available to be released during the fire and that the resuspension of any hazardous material left at the bottom of the pit as a result of the fire is negligible. This is a reasonable assumption since resuspension rate from the floor of a pit several feet below ground would be several orders of magnitude below the suspension rate due to thermal stress (DOE-HDBK-3010-94).

- For purposes of calculating radiological dose consequences, the fire is assumed to last for less than two hours. This means that the more conservative acute 99.5 percentile integrated atmospheric dispersion coefficient $X / Q^{\prime}$ without plume meander is used to calculate dose consequence (Van Keuren 1996a).

- The airborne release fraction (ARF) and respirable fraction (RF) discussed in Mishima for the thermal stress on an aqueous solution or air-dried salts under gasoline fire on a porous or otherwise absorbing (i.e., cracks, depressions) surface are considered to be appropriate and bounding for this analysis. The bounding values chosen for this accident are $A R F=5 \times 10^{-3}$ and $R F=0.4$, as Tisted on page 3-6 of DOE-HDBK-3010-94. Since the introduction of gasoline into the pit would result in mixing of waste with the gasoline, the chosen values of the ARF and RF are considered to be appropriate, bounding, and conservative for use in this analysis. Additionally, this assumption bounds the release of powders and the release from contaminated surfaces (DOE-HDBK-3010-94, pp. 4-61 and 5-21) due to thermal stress.

- Toxicological exposure consequences depend on the concentration of toxic material in the air (Van Keuren 1996b). Since the risk acceptance guidelines are stated in 15 minute averages, it was conservatively assumed that all of the combustible material was consumed and released in the first 15 minutes of the fire (a)though the fire is assumed to last for a longer period of time).

- A crane or a support vehicle travels no more than $150 \mathrm{~m}$ per day close enough to a pit for fuel from a ruptured fuel tank to flow into the pit. An assumption regarding the distance traveled by vehicles in and around pits is required in order to estimate an accident frequency.

\subsection{ANALYTICAL METHODS AND CALCULATIONS}

The analyzed unmitigated accident bounds the consequences for any of the hazards associated with fires in contaminated areas. The accident scenario assumes a one inch layer of dried out waste in the form of a powdery residue on the bottom of a valve pit. Fuel spills into the pit from a ruptured fuel tank and ignites. Both radioactive and toxic particulates are released to the atmosphere as influenced by the fire.

\section{Airborne Source Term Released:}

The first step in calculating the dose is to derive the airborne source term, i.e., the amount of airborne radioactive material generated by the 
accident that is available for transport to the maximum onsite and offsite individuals. As presented in Airborne Release Fractions/Rates and Respirable Fractions for Nonreactor Nuclear Facilities (DOE-HDBK-3010-94), the airborne source term is typically estimated by the following formula:

$$
\text { Source term }(Q)=\text { MAR } \times \text { DR } \times \text { ARF } \times R F \times L P F
$$

where

$$
\begin{aligned}
M A R & =\text { material-at-risk } \\
D R & =\text { damage ratio } \\
A R F & =\text { airborne release fraction } \\
R F & =\text { respirable fraction } \\
L P F & =\text { leak path factor } .
\end{aligned}
$$

The MAR is the amount of material available to be acted on by accident-induced physical stresses such as temperature or pressure. The OR is the fraction of the MAR actually impacted by the accident. An interdependency exists between the MAR and the DR, i.e., if it is predetermined that certain types of material will not be affected by a given accident, that material can be excluded from the MAR. In other words, the DR can be accounted for when defining the MAR.

The ARF is the coefficient used to estimate the amount of material suspended in air by the accident as an aerosol and thus available for transport due to the physical stresses of a specific accident. For mechanisms that continuously act to suspend material (e.g., a spray release), an ARR is required to estimate the potential airborne release from postulated accident conditions.

The RF is the fraction of airborne particles that can be transported through air and inhaled into the pulmonary region of the human respiratory system, and includes particles having a 10- $\mu \mathrm{m}$ aerodynamic equivalent diameter (AED) or less (DOE-HDBK-3010-94). The AED is the diameter of sphere of density $\left(1 \mathrm{~g} / \mathrm{cm}^{3}\right)$ that exhibits the same terminal velocity as the particle in question.

The LPF is the fraction of the material in the aerosol transported through some confinement deposition or filtration mechanism. Leak path factors are developed as applicable based upon (1) established relationships among the size of the particulate material, airborne transport mechanisms, and losses by deposition; or (2) specified filtration efficiencies

$$
\text { (DOE-HDBK-3010-94). }
$$

\section{Material at Risk (MAR) and Damage Ratio (DR)}

The MAR is calculated for a $2.54 \mathrm{~cm}$ (1-in.) layer of aging waste on the floor of a valve pit that is $3.048 \mathrm{~m}(10 \mathrm{ft})$ wide by $3.6576 \mathrm{~m}$ ( $12 \mathrm{ft}$ ) long. The drain is located near the corner of the pit. The elevation of the pit at the drain is $3.81 \mathrm{~cm}(1.5-i n$.$) lower than at the walls (see Section 2.0,$ 
Analysis Input). Based on the above dimensions the volume of the aging waste on the pit floor is calculated using the equation for the volume of a pyramid.

$$
V_{\text {pyramid }}=1 / 3 \cdot(A)(h)
$$

Where: $A$ is the area of the base

$h$ is the height of the pyramid

The area of the pyramid based formed by the waste on the pit floor is related to its height. For waste filling the pit $2 / 3$ of the distance to the walls (i.e., $2.54 \mathrm{~cm}$ [ 1 in.] of waste in a pyramid shaped container $3.81 \mathrm{~cm}$ [1.5 in.] deep), the area will be:

$$
A_{\text {waste }}=2 / 3\left(L_{p i t}\right) \cdot 2 / 3\left(W_{\text {pit }}\right)
$$

Combining with the previous equation gives:

$$
V_{\text {pyramid }}=1 / 3 \cdot\left[2 / 3\left(L_{p i t}\right) \cdot 2 / 3\left(W_{p i t}\right)\right](h)
$$

Calculating the volume of waste gives:

$$
(1 / 3)\left[(2 / 3)(3.048 \mathrm{~m}) \cdot(2 / 3)(3.6576 \mathrm{~m}) \cdot(0.0254 \mathrm{~m}) \cdot\left(1000 \mathrm{~L} / \mathrm{m}^{3}\right)\right] \cong 42.0 \mathrm{~L}
$$

The calculation of the MAR takes into account the fact that the floor slopes towards the drain from al1 4 walls (See the sketch of the pit and floor in Appendix B) and assumes that the 4 floor segments intersect at the drain. No credit is taken for the volume occupied by the protruding drain.

Since all of the waste material in the pit is assumed to be involved (i.e., exposed to the fire), the damage ratio (DR) equals 1 .

\section{Airborne Release Fraction (ARF), Respirable Fraction (RF), and Leak Path Factor (LPF)}

In the above scenario, release and dispersion of airborne particles comes from the mixing and heating of waste material in a gasoline fire. The airborne release due to the fire was conservatively assumed to be sufficiently bounded by the ARF and RF for contaminated organic liquids under thermal stress (DOE-HDBK-3010-94, p. 3-6). These values are:

$$
\begin{aligned}
& \text { ARF }=5.0 \times 10^{-3} \\
& R F=0.4
\end{aligned}
$$

Once the waste is aerosolized by the fire it leaks directly to the atmosphere, $L P F=1$.

\section{Calculation of the Airborne Source Term Released in this Accident Scenario}

$$
\begin{aligned}
\text { Source Term }(Q) & =\text { MAR } \times \text { DR } \times \text { ARF } \times \operatorname{RF} \times \mathrm{LPF} \\
& =(42.0 \mathrm{~L}) \cdot(1) \cdot\left(5.0 \times 10^{-3}\right) \cdot(0.4) \cdot(1) \\
\text { Source Term }(Q) & =8.4 \times 10^{-2} \mathrm{~L}
\end{aligned}
$$




\subsection{RADIOLOGICAL DOSE CONSEQUENCE ANALYSIS}

Given an airborne source term, the doses from the inhalation and ingestion pathways are calculated by the following formulas:

Inhalation:

$$
D_{\mathrm{inh}}(S v)=Q(L) \times \frac{X}{Q^{\prime}}\left(\frac{s}{m^{3}}\right) \times R\left(\frac{m^{3}}{s}\right) \times U L D_{\mathrm{inh}}\left(\frac{S v}{L}\right)
$$

Ingestion:

$$
D_{\text {ing }}(S v)=Q(L) \times \frac{X}{Q^{1}}\left(\frac{s}{m^{3}}\right) \times U L D_{\text {ing }}\left(\frac{s v-m^{3}}{s-L}\right)
$$

where

$$
\begin{aligned}
D_{\text {inh }} & =\text { dose due to inhalation (Sv) } \\
D_{\text {ing }} & =\text { dose due to ingestion (Sv) } \\
Q & =\text { respirable source term }(\mathrm{L}) \\
X / Q^{\prime} & =\text { atmospheric dispersion coefficient without plume meander }\left(\mathrm{s} / \mathrm{m}^{3}\right) \\
R & \left.=\text { breathing rate (for acute exposure, } 3.3 \times 10^{-4} \mathrm{~m}^{3} / \mathrm{s}\right) \\
U L D_{i n h} & =\text { inhalation unit liter dose }(\mathrm{Sv} / \mathrm{L}, \text { calculated below) } \\
U L L D_{i n g} & =\text { ingestion unit liter dose }\left(\mathrm{Sv}-\mathrm{m}^{3} / \mathrm{s}-\mathrm{L},\right. \text { calculated below). }
\end{aligned}
$$

For the inhalation pathway, the dose calculated is the 50-year committed effective dose equivalent (CEDE) defined as the dose received by the individual during a 50-year period following the uptake. For the maximum onsite individual, this dose must be combined with that due to external exposure (if any) to yield the TEDE. For the ingestion pathway, the dose calculated is the CEDE from ingestion plus the dose due to external exposure (e.g., ground shine) during the first 24 hours after the release. Combining the ingestion dose with the inhalation dose yields the TEDE for the maximum offsite individual.

\section{Calculation of the Unit Liter Doses for Source Term in this Scenario}

The source material for this accident was assumed to be AWF waste composed of 33 vol\% solids and 67 vol\% liquids. Therefore, using the ULDs for AWF 1 iquids and solids given in Table 1 gives: 


$$
\begin{aligned}
U L D_{\text {inhal }} & =\left(1.7 \times 10^{6} \times 0.33+1.4 \times 10^{3} \times 0.67\right) \frac{S V}{L} \\
& =5.62 \times 10^{5} \frac{S v}{L} \\
U L D_{\text {ing }} & =(8.1 \times 0.33+0.092 \times 0.67) \frac{s v-m^{3}}{s-L} \\
& =2.73 \frac{s v-m^{3}}{s-L}
\end{aligned}
$$

\section{Radiological Inhalation Dose Consequence}

$$
\begin{aligned}
D_{\text {onsite }} & =8.4 \times 10^{-2} \mathrm{~L} \times 3.41 \times 10^{-2} \frac{\mathrm{s}}{\mathrm{m}^{3}} \times 3.3 \times 10^{-4} \frac{\mathrm{m}^{3}}{\mathrm{~s}} \times 5.62 \times 10^{5} \frac{\mathrm{sV}}{\mathrm{L}} \\
& =5.31 \times 10^{-1} \mathrm{SV} \\
D_{\text {offsite }} & =8.4 \times 10^{-2} \mathrm{~L} \times 2.83 \times 10^{-5} \frac{\mathrm{s}}{\mathrm{m}^{3}} \times 3.3 \times 10^{-4} \frac{\mathrm{m}^{3}}{\mathrm{~s}} \times 5.62 \times 10^{5} \frac{\mathrm{sV}}{\mathrm{L}} \\
& =4.41 \times 10^{-4} \mathrm{SV}
\end{aligned}
$$

\section{Radiological Ingestion Dose Consequence}

Ingestion doses are only calculated for the offsite receptor (Cowley 1996).

$$
\begin{aligned}
D_{\text {offsite }} & =8.4 \times 10^{-2} \mathrm{~L} \times 2.83 \times 10^{-5} \frac{\mathrm{s}}{\mathrm{m}^{3}} \times 2.73 \frac{\mathrm{sv}-\mathrm{m}^{3}}{\mathrm{~s}-\mathrm{L}} \\
& =6.49 \times 10^{-6} \mathrm{SV}
\end{aligned}
$$

\section{Total Radiological Dose Consequences}

$$
\begin{aligned}
& D_{\text {onsite }}=5.31 \times 10^{-1} \mathrm{~Sv} \\
& D_{\text {offsite }}=4.47 \times 10^{-4} \mathrm{~Sv}
\end{aligned}
$$




\subsection{TOXICOLOGICAL EXPOSURE CONSEQUENCE ANALYSIS}

The methodology that is used to calculate toxicological exposure consequences is documented in WHC-SD-WM-SARR-011, Rev. 2, Toxic Chemical Considerations for Tank Farm Releases. In this method, the released quantity is multiplied by the ARR and then multiplied by the appropriate sum-of-fraction (SOF) value from Table 3-8 of Van Keuren (1996). Table 3-8 of Van Keuren (1996b) is included in Appendix $D$ and the important values for this scenario are reproduced in Table 3 below.

Table 3. Sum-of-Fraction of Risk Guidelines for a Unit Release of Chemicals. (from Table 3-8, Van Keuren [1996])

\begin{tabular}{|c|c|c|}
\hline $\begin{array}{c}\text { Tank Waste (Units of Sum-of- } \\
\text { Fractions follow Tank Waste Type) }\end{array}$ & $\begin{array}{c}\text { Maximum } \\
\text { Individual }\end{array}$ & $\begin{array}{c}\text { Accident Frequency } \\
>10^{-2}\end{array}$ \\
\hline Double-Shell Liquids (s/L) & Onsite & $1.0 \times 10^{4}$ \\
\hline Double-Shell Liquids (s/L) & Offsite & 8.4 \\
\hline Double-Shell Solids (s/L) & Onsite & $1.8 \times 10^{4}$ \\
\hline Double-Shell Solids (s/L) & Offsite & $1.9 \times 10^{2}$ \\
\hline
\end{tabular}

- The sum-of-fraction values for the double-shell liquids and solids include the source term values for the aging waste facility liquids and solids, respectively.

Composite sum-of-fraction values are calculated for the 67 vol\% Aging Waste Facility (AWF) liquids and 33 vol\% AWF solids just as for the radiological source term.

$$
\begin{aligned}
\text { SOF }_{\text {onsite }} & =(.33) \cdot\left(1.8 \times 10^{4} \mathrm{~s} / \mathrm{L}\right)+(.67)\left(1.0 \times 10^{4} \mathrm{~s} / \mathrm{L}\right) \\
& =1.3 \times 10^{4} \mathrm{~s} / \mathrm{L} \\
\text { SOF }_{\text {offsite }} & =(.33) \cdot\left(1.9 \times 10^{2} \mathrm{~s} / \mathrm{L}\right)+(.67)(8.4 \mathrm{~s} / \mathrm{L}) \\
& =6.8 \times 10^{1} \mathrm{~s} / \mathrm{L}
\end{aligned}
$$

For purposes of calculating toxic releases, an accident duration time of 15 minutes $(900 \mathrm{~s})$ is conservatively assumed. This gives an airborne release rate (ARR) of:

$$
\begin{aligned}
\text { ARR } & =1 / 900 \mathrm{~s} \\
& =1.1 \times 10^{-3} \mathrm{~s}^{-1}
\end{aligned}
$$

The amount released $(Q)$ in the accident scenario, as calculated previously, was $8.4 \times 10^{-2}$ L. This amount of waste is conservatively assumed to be released in the first 15 minutes of the fire, although the fire is likely to last longer, as discussed in the Assumptions. 
the equation:

The toxicological exposure consequences are therefore calculated using

Toxicological Exposure Consequences $=Q \cdot A R R \cdot S O F$

The exposure consequences $\left(D_{\text {onsite }}\right)$ to the onsite receptor are:

$$
\begin{aligned}
D_{\text {onsite }} & =\left(8.4 \times 10^{-2} \mathrm{~L}\right) \cdot\left(1.1 \times 10^{-3} / \mathrm{s}\right) \cdot\left(1.3 \times 10^{4} \mathrm{~s} / \mathrm{L}\right) \\
& =1.2
\end{aligned}
$$

The exposure consequences $\left(D_{\text {offsite }}\right)$ to the onsite receptor are:

$$
\begin{aligned}
D_{\text {offsite }} & =\left(8.4 \times 10^{-2} \mathrm{~L}\right) \cdot\left(1.1 \times 10^{-3} / \mathrm{s}\right) \cdot\left(6.8 \times 10^{1} \mathrm{~s} / \mathrm{L}\right) \\
& =6.3 \times 10^{-3}
\end{aligned}
$$

\subsection{ANALYSIS RESULTS}

The results of the calculations (both radiological doses and toxicological exposures) are given in Table 4 . The radiological results are well within risk evaluation guidelines for offsite receptors but over the risk evaluation guidelines for an onsite receptor for an anticipated event.

The toxicological exposure consequence results are well within the risk evaluation guidelines for offsite receptors but slightly over the risk

\begin{tabular}{|c|c|c|c|c|}
\hline \multirow{2}{*}{$\begin{array}{l}\text { Receptor/ } \\
\text { Hazard }\end{array}$} & \multirow{2}{*}{$\begin{array}{l}\text { Calculated } \\
\text { Dose/Exposure }\end{array}$} & \multicolumn{3}{|c|}{ Risk Guidelines } \\
\hline & & Anticipated & Unlikely & $\begin{array}{l}\text { Extremely } \\
\text { Unlikely }\end{array}$ \\
\hline $\begin{array}{l}\text { Offsite/ } \\
\text { Radiological }\end{array}$ & $\begin{array}{c}4.41 \times 10^{-2} \\
\mathrm{rem}\end{array}$ & $0.1 \mathrm{rem}$ & 0.5 rem & 4 rem \\
\hline $\begin{array}{l}\text { Onsite/ } \\
\text { Radiological }\end{array}$ & 53.1 rem & $0.5 \mathrm{rem}$ & 5 rem & $10 \mathrm{rem}$ \\
\hline $\begin{array}{l}\text { Offsite/ } \\
\text { Toxicological }\end{array}$ & $6.3 \times 10^{-3}$ & 1 & 1 & 1 \\
\hline $\begin{array}{l}\text { Onsite/ } \\
\text { Toxicological }\end{array}$ & 1.2 & 1 & 1 & 1 \\
\hline
\end{tabular}
evaluation guidelines for an onsite receptor.

Table 4. Radiological Dose and Toxicological Exposure Consequences for Fire in a Contaminated Area Accident Scenario. 


\subsection{CONCLUSIONS}

For an offsite receptor the calculated radioactive dose and toxicological exposure consequences are well within the risk evaluation guidelines. However, for an onsite receptor, the calculated radiological dose and toxicological exposure consequences are above the risk guidelines for an anticipated event.

Since the onsite guidelines are exceeded for this unmitigated accident with a frequency of anticipated, controls are necessary to either mitigate or prevent the hazards associated with this accident scenario and are documented in the TWRS FSAR. It should be noted that the onsite radiological guidelines are exceeded regardless of the frequency.

\subsection{REFERENCES}

Van Keuren, J. C., 1996a, WHC-SD-WM-SARR-016, Rev. 2, Tank Waste Compositions and Atmospheric Dispersion Coefficients for use in ASA Consequence Assessments, Westinghouse Hanford Company, Richland, Washington.

Van Keuren, J. C., 1996b, WHC-SD-WM-SARR-011, Rev. 2, Toxicological Chemical Considerations for Tank Farm Releases, Westinghouse Hanford Company, Richland, Washington.

DOE-HDBK-3010-94, 1994, "DOE Handbook Airborne Release Fractions/Rates and Restorable Fraction for Nonreactor Nuclear Facilities," U.S. Department of Energy, Richland, Washington.

Cowley, W. L., 1996, Development of Radiological Concentrations and Unit Liter Doses for TWRS FSAR Radiological Consequence Calculations, WHC-SD-WM-SARR-037, Rev. 0, West inghouse Hanford Company, Richland, Washington.

Harwood, D. W., and E. R. Russe1, 1990, Present Practices of Highway Transportation of Hazardous Materials, FHWA-RD-89-013, U.S. Department of Transportation.

H\&R 522-1, 1995, Recommended Onsite Transportation Risk Management Methodology, H\&R Technical Associates, Inc. Oak Ridge, Tennessee, (prepared for Westinghouse Hanford Company Packaging Engineering).

WHC 1991, Safety Analysis Manual, WHC-CM-4-46, Section 4.0, Rev. 1, November 15, 1991, Westinghouse Hanford Company, Richland, Washington. 
WHC-SD-WM-CN-056 REV 2

\section{APPENDIX A \\ ACCIDENT FREQUENCY DEVELOPMENT}

17 of 38 


\section{WHC-SD-WM-CN-056 REV 2}

This page intentionally left blank. 
This accident is caused by a human error in positioning a crane or support vehicle. The hazard analysis placed this accident in the "Anticipated" category with frequency $>10^{-2}$ per year. However, an unmitigated accident frequency can be calculated for this, given the number of miles per year by a crane or support vehicle near a pit and the vehicle accident statistics involving fires compiled by the U.S. Department of Transportation (DOT) (Harwood and Russel 1990).

The highest accident frequency per mile for trucks operating on a rural roadway is according to data compiled in (Harwood and Russel 1990).

$$
f_{\text {init }}=4.5 \times 10^{-6} \frac{\text { collision }}{\text { mile }}
$$

This is approximately the per mile accident rate recommended for Hanford Site and is considered to be conservative for congested areas (H\&R 522-1, 1995, p. B-7).

The total distance traveled in a year by a crane or a support vehicle near a pit is

$$
\begin{aligned}
d & =365 \frac{\text { day }}{\text { year }} \times 150 \frac{\mathrm{m}}{d a y} \times \frac{\text { mile }}{1609 m} \\
& =34 \frac{\text { mile }}{\text { year }}
\end{aligned}
$$

The accident initiation frequency per year for the collision of a vehicle with a pit is

$$
\begin{aligned}
f & =4.5 \times 10^{-6} \frac{\text { collision }}{\text { mile }} \times 34 \frac{\text { mile }}{\text { year }} \\
& =1.5 \times 10^{-4} \frac{\text { collision }}{\text { year }}
\end{aligned}
$$

The frequency of a fire resulting from a collision not involving another vehicle is (Ref. 6)

$$
t_{\text {fire }}=6 \times 10^{-3} \frac{\text { fire }}{\text { collision }}
$$


Therefore, the unmitigated event frequency for a fire in a pit due to a collision with a pit curb is estimated to be

$$
\begin{aligned}
f & =6 \times 10^{-3} \frac{\text { fire }}{\text { collision }} \times 1.5 \times 10^{-4} \frac{\text { collision }}{\text { year }} \\
& =9.0 \times 10^{-7} / \text { year }
\end{aligned}
$$

This frequency is vehicle and location dependent and would therefore be multiplied by the total number of vehicles available and the number of locations where the hazard exists. 
WHC-SD-WM-CN-056 REV 2

APPENDIX B

SKETCHES OF TYPICAL VALVE PITS 
WHC-SD-WM-CN-056 REV 2

This page intentionally left blank. 
WHC-SD-WM-CN-056 REV 2

WHC-50-WAT-158-001, Vol. 2, ReV. 0 it

Figure 1-53. Vaive Pits 24]-AX-A and -8 .
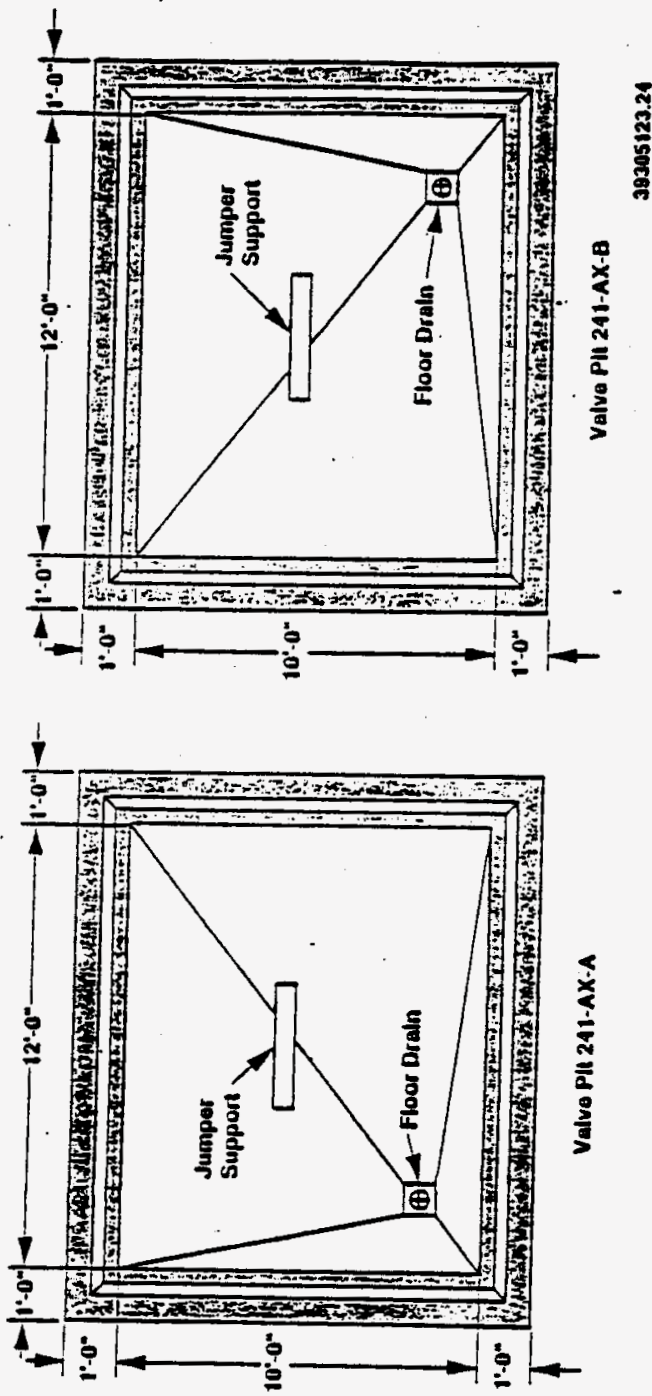
WHC-SD-WM-CN-056 REV 2

This page intentionally left blank. 
WHC-SD-WM-CN-056 REV 2

APPENDIX C

INFORMATION VALIDATION FORM

25 of 38 
WHC-SD-WM-CN-056 REV 2

This page intentionally left blank.

26 of 38 


\begin{tabular}{|l|l|l|}
\hline $\begin{array}{l}\text { Name of Originator } \\
\text { Roald D. Graves }\end{array}$ & $\begin{array}{l}\text { Organization of Team 2 } \\
\text { FSAR CHAPER 3 }\end{array}$ & $\begin{array}{l}\text { Date } \\
\text { S/1/96 }\end{array}$ \\
\hline
\end{tabular}

Sutement of Problem For the Fire in Coseaminated Area aceideat the material at sisk (MAR) is required. This is defided as the waste material that could acounulate in a pitriser and be available for combusrion.

Asomptions:

(1) The material at risk in this aceident is bounded by a $t$ in layes of waste at the bottom of a typical valve pit. The typieal pit is $10 \mathrm{ft}$ by 12 ff wich a drain in one comes. The drain may have a $I$ in lip above the floor that could cause waste from 2 leax to stagnant in the pit up to a depth of 1 inch at the drin. The floor of the pit slopes towards the drain from all sides of the pit. The floor elevacion at the walls of the pit is 1.5 inctes above the drin. Based on this taes the volume of waste is bounded by $s \mathrm{ft}^{3}$.

(2) The composicion of waste is 67 percens AWF liquids and 33 perceat AWF solids.

4

\begin{tabular}{|c|c|c|c|}
\hline Alternacives & & $\begin{array}{l}\text { Consequences to } \mathrm{A} \\
6\end{array}$ & termatives \\
\hline $\begin{array}{l}\text { Decision Reached } \\
7\end{array}$ & & $\begin{array}{l}\text { Basis for Decision } \\
8\end{array}$ & \\
\hline $\begin{array}{l}\text { Dace Requesied } \\
9\end{array}$ & $\begin{array}{l}\text { Sere To } \\
10\end{array}$ & & $\begin{array}{l}\text { Date Requested By } \\
5 / 13 / 96\end{array}$ \\
\hline
\end{tabular}

Response "1 For the purpose of this analysis, the numbers you bave provided can be used. I would offer that you look at Double Shell Tank Part B Permit Application Chapt. 4.0, whish has cables wich pit dimeasions if it becomes aecessary. For the Plant :esponse to composition of anste, see IVF-Chapter 3-itl.

12

Response $\$ 2$

13

\begin{tabular}{|c|c|}
\hline Aunchmeats (List) & Referepces (List) is \\
\hline 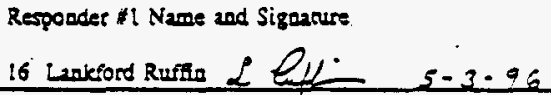 & $\begin{array}{l}\text { Responder } \$ 2 \text { Name and Signacure } \\
17\end{array}$ \\
\hline Filed: & Routed: \\
\hline
\end{tabular}


WHC-SD-WM-CN-056 REV 2

This page intentionally left blank. 
WHC-SD-WM-CN-056 REV 2

APPENDIX D

SUM-OF-FRACTION OF RISK GUIDELINES FOR UNIT LITER RELEASE OF CHEMICALS 
WHC-SD-WM-CN-056 REV 2

This page intentionally left blank. 
Table 3-8. Sum-of-Fraction of Risk Guidelines for a Unit Release of Chemicals and Gases. . (3 sheets) .

The sum of tractions are rultiplied by the release rate for continuous release and release amount fior a purf releases. Release rates for continuous releases are in units of liters per second for liquids and solids, and $\mathrm{m} 3 / \mathrm{s}$ for gases. Puff release quantities are in units of liters for solids and liquids and $\mathrm{m} 3$ for gases.

\begin{tabular}{|c|c|c|c|c|}
\hline \multirow{2}{*}{$\begin{array}{l}\text { Tank waste type (Units of sum of } \\
\text { fractions follow tank waste type) }\end{array}$} & \multirow{2}{*}{$\begin{array}{l}\text { Maximum } \\
\text { individual }\end{array}$} & \multicolumn{3}{|c|}{ Accident trequency, $1 / y r$} \\
\hline & & $1 \cdot 10-2$ & $10-2 \cdot 10-4$ & $10-\cdot 10-6$ \\
\hline \multicolumn{5}{|c|}{ DST or SST solid or liquid continuous release } \\
\hline Single-shell liquids(s/L) & Onsite & $9.6 E+03$ & $7.5 \mathrm{E}+02$ & $2.0 E+02$ \\
\hline Single-shell liquids(s/L) & Offsite & $8.0 E+00$ & $8.0 E+00$ & $6.2 \mathrm{E}-0 !$ \\
\hline Single-shell solids(s/L) & Onsite & $4.0 E-04$ & $2.1 E+03$ & $1.0 \mathrm{E} \div 03$ \\
\hline Single-shell solids(siL) & Ortsite & $9 .+E+01$ & $3.3 E \div 01$ & $1.7 E-01$ \\
\hline Double-shell liquids(s/L) & Onsite & $1.0 E+04$ & $7.5 E+02$ & $2.1 E+02$ \\
\hline Double-she!l liquids(s/L) & Otfisite & $8.1 E-\infty 0$ & $8.1 E+\infty 0$ & $6.2 E-01$ \\
\hline Double-sheil solids ( $s / L$ ) & Onsite & $1.8 E+04$ & $3.3 \mathrm{E}+03$ & $6.3 E+02$ \\
\hline Double-shell solids(s/L) & Offsire & $1.9 E+02$ & $1.5 E+01$ & $2.8 \bar{E}+\infty 0$ \\
\hline \multicolumn{5}{|c|}{ DST or SST liquid or solid putf release } \\
\hline Single-shell liquids $(L-1)$ & Onsite & $2.8 E-03$ & $2.2 E+02$ & $5.7 E-01$ \\
\hline Single-shell liquids $(L \cdot 1)$ & Offsite & $3.2 E-02$ & $3.2 \mathrm{E}-02$ & $2.5 \mathrm{E}-03$ \\
\hline Single-shell solids (L-I) & Onsite & $1.2 E+04$ & $6.0 E+03$ & $2.9 \mathrm{E} \div 02$ \\
\hline Single-shell solids $(\mathcal{L} \cdot \mathrm{i})$ & Offsite & $3.8 \mathrm{E}-0 \mathrm{~L}$ & $1.3 \mathrm{E}-0 \mathrm{i}$ & $6.9 E-02$ \\
\hline Double-sheil liquids $(\mathbb{L} \cdot 1)$ & Onsite & $2.9 E+03$ & $2.2 E+02$ & $6.0 \varepsilon+0 !$ \\
\hline Double-shell liquids (L-1) & Offsite & $3.4 E-02$ & $3.4 E-02$ & $2.5 E-03$ \\
\hline Double-shell solids (L-i) & Onsite & $5.2 \bar{E}+03$ & $9.7 E \div 02$ & $1.8 \mathrm{E}-02$ \\
\hline Double-shetl solids $(\mathcal{L}-i)$ & Onsite & $7.7 \mathrm{E}-\mathrm{Ol}$ & $5.9 \mathrm{E}-02$ & $1.1 \mathrm{E}-02$ \\
\hline \multicolumn{5}{|c|}{ Ftemante-is } \\
\hline 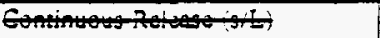 & Ongite & $t=04$ & 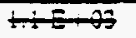 & 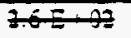 \\
\hline (1) & Oninite & $\div=0$ & $\because 2=0$ & $6 \div=04$ \\
\hline | & Gnstr & $3+5=03$ & 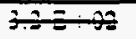 & $7=E-4$ \\
\hline 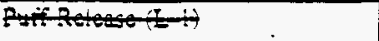 & $\theta$ Offits & $\div 1=02$ & $+2=02$ & $+4=0$ \\
\hline
\end{tabular}


WHC-SD-WM-CN-056 REV 2

This page intentionally left blank. 
WHC-SD-WM-CN-056 REV 2

APPENDIX E

PEER REVIEW AND HEDOP REVIEW CHECKLISTS

33 of 38 
WHC-SD-WM-CN-056 REV 2

This page intentionally left blank. 


\section{CHECKLIST FOR PEER REVIEW}

Document Reviewed: WHC-SD-WM-CN-056, Rev. 1, Fire in a Contaminated Area.

Scope of Review: Entire document.

$\frac{\text { Yes } N_{0} N A}{\text { X] }][] \text { * }}$

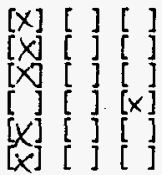

[X] [ ] [ ]

$[x][][]$

[x] [ ] [ ]

[]$\left[\begin{array}{ll}] & {[x]} \\ {[} & {[x]}\end{array}\right]$

[x] [ ] [ ]

$[x]\left[\begin{array}{lll}{[} & {[}\end{array}\right]$

[x] [ ] [ ]

[x] [ ] [ ]

Previous reviews complete and cover analysis, up to scope of this review, with no gaps.

Problem completely defined.

Accident scenarios developed in a clear and logical manner.

Necessary assumptions explicitly stated and supported.

Computer codes and data files documented.

Data used in calculations explicitly stated in document.

Data checked for consistency with original source information as applicable.

Mathematical derivations checked including dimensional consistency of resuits.

Models appropriate and used within range of validity or use outside range of established validity justified.

Hand calculations checked for errors. Spreadsheet results should be treated exactly the same as hand calculations. Software input correct and consistent with document reviewed. Software output consistent with input and with results reported in document reviewed.

Limits/criteria/guidelines applied to analysis results are appropriate and referenced. Limits/criteria/guidelines checked against references.

Safety margins consistent with good engineering practices. Conclusions consistent with analytical results and applicable Timits.

Results and conclusions address all points required in the problem statement.

Format consistent with appropriate NRC Regulatory Guide or other standards

[ ] $[x]$ * Review calculations, comments, and/or notes are attached.

\section{[x] [ ] [ ] Document approved.}

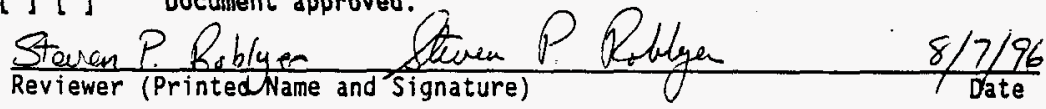

* Any calculations, comments, or notes generated as part of this review should be signed, dated and attached to this checklist. Such material should be labeled and recorded in such a manner as to be intelligible to a technically qualified third party. 


\section{HEDOP REVIEM CHECKLIST \\ for \\ Radiological and Nonradiological Release Calculations}

Document reviewed (include title or description of calculation, document number, author, and date, as applicable):

WHC-SD-WM-CN-056, Rev. 1, Fire in a Contaminated Area.

Submitted by: Grant W. Ryan

Date Submitted: $8 / 7 / 96$

Scope of Review: Radiological and Toxicological Calculations.

YES NO* N N $\quad$ /A

\$4 [ ] [ ] 1. A detailed technical review and approval of the environmental transport and dose calculation portion of the analysis has been performed and documented.

\[ ] [ ] 2. Detailed technical review(s) and approval(s) of scenario and release determinations have been performed and documented.

[ ] [ ] 3. HEDOP-approved code(s) were used.

[] [] by 4. Receptor locations were selected according to HEDOP recommendations.

DA [ ] [ ] 5. All applicable environmental pathways and code options were included and are appropriate for the calculations.

(4) [ ] [ ] 6. Hanford site data were used.

[] [ ] $]$ 7. Model adjustments external to the computer program were justified and performed correctly.

\$. [ ] [ ] 8. The analysis is consistent with HEDOP recommendations.

(2) 9. Supporting notes, calculations, comments, corment resolutions, or other information is attached. (Use the "Page 1 of $X "$ page numbering format and sign and date each added page.)

Dt [ ] 10. Approval is granted on behalf of the Hanford Environmental Dose Overview Panel.

- A11 "NO" responses must be explained and use of nonstandard methods justified.

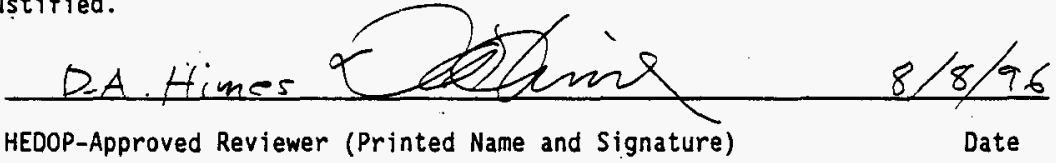

COMMENTS (add additional signed and dated pages if necessary): 


\section{CHECKLIST FOR PEER REVIEW}

Document Reviewed: WHC-SD-WM-CN-056, Rev. 2, Fire in a Contaminated Area.

Scope of Review: Entire document.

$\frac{\text { Yes No NA }}{[x][][]}$ *

$\begin{array}{lll}{[x]} & {[]} & {[]} \\ {[x]} & {[]} & {[]} \\ {[x]} & {[]} & {[]} \\ {[]} & {[]} & {[x]} \\ {[x]} & {[]} & {[]} \\ {[x]} & {[]} & {[]}\end{array}$

$[x][][]$

$[x][][]$

[X]:[ ] [ ]

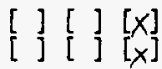

[X] [ ] [ ]

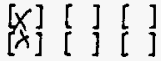

$[x][][]$

$[x[][]$

[ ] [X] *

Previous reviews complete and cover analysis, up to scope of this review, with no gaps.

Problem completely defined.

Accident scenarios developed in a clear and logical manner.

Necessary assumptions explicitiy stated and supported.

Computer codes and data files documented.

Data used in calculations explicitly stated in document.

Data checked for consistency with original source information as applicable.

Mathematical derivations checked including dimensional consistency of results.

Models appropriate and used within range of validity or use outside range of established validity justified.

Hand calculations checked for errors. Spreadsheet results should be treated exactly the same as hand calculations. Software input correct and consistent with document reviewed. Software output consistent with input and with results reported in document reviewed.

Limits/criteria/guidelines applied to analysis results are appropriate and referenced. Limits/criteria/guidelines checked against references.

Safety margins consistent with good engineering practices. Conclusions consistent with analytical results and applicable limits.

Results and conclusions address all points required in the problem statement.

Format consistent with appropriate NRC Regulatory Guide or other standards

[X] [ ] [ ] Document approved.

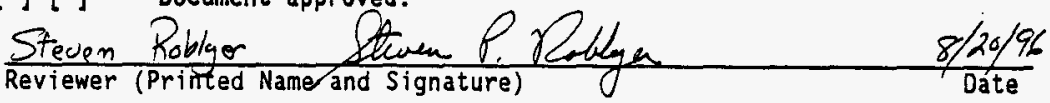

* Any calculations, comments, or notes generated as part of this review should be signed, dated and attached to this checklist. Such material should be labeled and recorded in such a manner as to be intelligible to a technically qualified third party. 


\section{WHC-SD-WM-CN-056 REV 2 \\ HEDOP REVIEN CHECKLIST \\ for \\ Radiological and Nonradiological Release Calculations}

Document reviewed (include title or description of calculation, document number, author, and date, as applicable):

WHC-SD-WM-CN-056, Rev. 2, Fire in a Contaminated Area.

Submitted by: Grant W. Ryan Date Submitted: 8/22/96

Scope of Review: Radiological Dose and Toxicological Exposure Calculations.

YES NO* N/A

Q [ ] [ ] 1. A detailed technical review and approval of the environmental transport and dose calculation portion of the analysis has been performed and documented.

[4 [ ] [ ] 2. Detailed technical review(s) and approval(s) of scenario and release determinations have been performed and documented.

[.] [ ] $\bowtie$ 3. HEDOP-approved code(s) were used.

[ [ ] 4. Receptor locations were selected according to HEDOP recommendations.

[X] [ ] [ ] 5. A1l applicable environmental pathways and code options

$\infty$ were included and are appropriate for the calculations.

[ [ ] [ ] 6. Hanford site data were used.

[] [ ] D 7. Model adjustments external to the computer program were justified and performed correctly.

D [ ] [ ] 8. The analysis is consistent with HEDOP recommendations.

9. Supporting notes, calculations, comments, comment resolutions, or other information is attached. (Use the "Page 1 of $X "$ page numbering format and sign and date each added page.)

$2[1$

10. Approval is granted on behalf of the Hanford Environmental Dose Overview Panel.

* A11 "NO" responses must be explained and use of nonstandard methods justified.

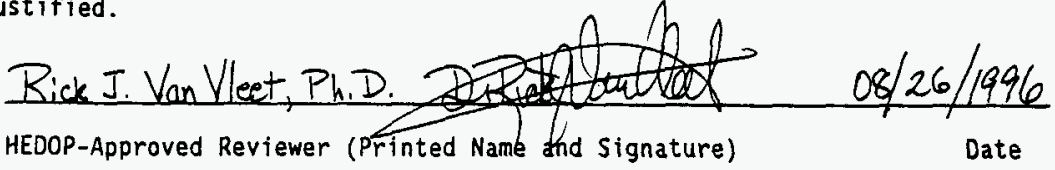

COMMENTS (add additional signed and dated pages if necessary): 


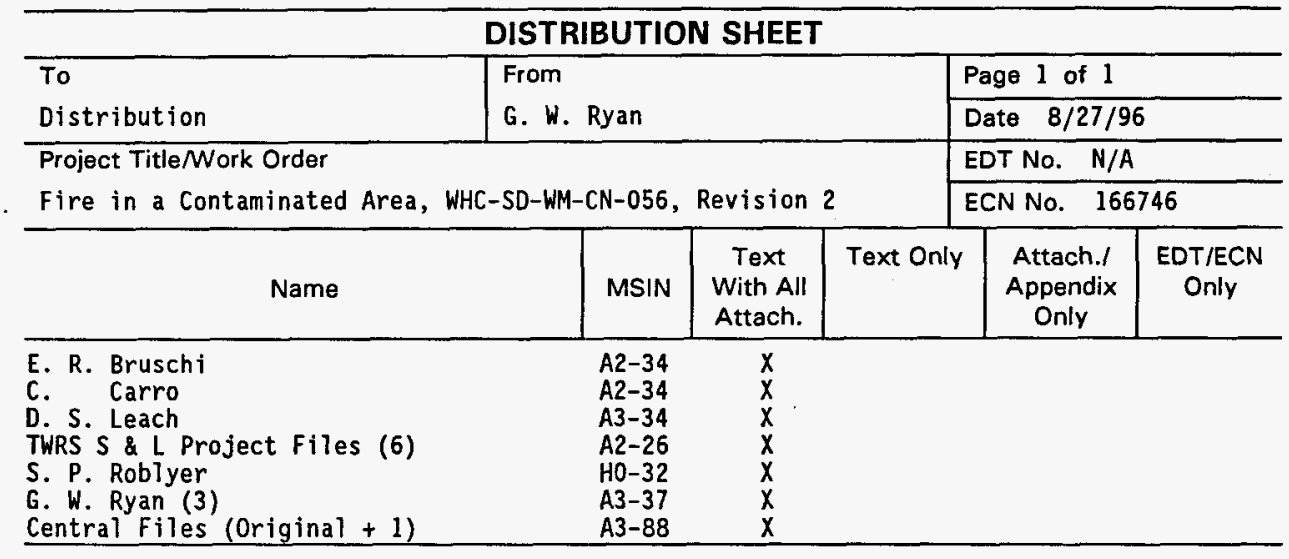

